\title{
Uterine artery embolization for the treatment of symptomatic myomas in Brazilian women
}

\author{
Hospital Leonor Mendes de Barros, São Paulo, Brazil
}

- Maurício Sena-Martins

- Cecilia Maria Roteli-Martins

- Valdir Tadin

- Gustavo Antonio de Souza

- Nestor Kisilevzky

- Felipe Lazar Junior

\section{....... INTRODUCTION}

Uterine myomas are benign tumors that mostly occur in women of reproductive age at a frequency ranging from 20 to $25 \%$ and are three times more common during the preclimacteric period. ${ }^{1}$ The dimensions of the tumors vary widely from $1 \mathrm{~mm}$ to $20 \mathrm{~cm}$ or more and their prevalence is difficult to estimate in most cases. Macro and microscopic examination of the uterus in specimens for anatomopathological study has shown a prevalence of $77 \% .^{2}$ Myomas occur especially among nulliparous obese black women with a family history of uterine myomatosis and hyperestrogenic syndromes, and they reach a considerable size in $50 \%$ of these women.

Although most women with myomas are asymptomatic, complaints of abnormal uterine bleeding characterized by increased menstrual flow volume, pain and symptoms of adjacent organ compression are the most frequent symptoms, occurring at rates of 10 to $40 \%{ }^{3}$ The estimated annual cost of the treatment of uterine myomatosis is close to three billion dollars in the United States, excluding the expenses related to morbidity and missed days of work by the women. Furthermore, intercurrences related to myomas cause a higher rate of hospital stay than Aids, breast or prostate cancer, dementia, cirrhosis, and epilepsy. ${ }^{4}$

The conservative treatment used depends on factors such as number and size of the myomas, intensity of symptoms, and the woman's age and wish to reproduce. The purpose of this type of treatment is to minimize the severity of bleeding and reduce the volume of the tumors. Such procedures are also used before surgery for myomectomy and hysterectomy. ${ }^{5}$

In Paris in 1992, Ravina et al. were the first to use embolization of the uterine arteries specifically for the treatment of myomas, and the results of their study were published in 1995. Their approach was based on the observation of symptom improvement among women who were submitted to this procedure in order to reduce intraoperative bleeding before myomectomy. ${ }^{6}$

In the United States, Goodwin et al. (1997) were the first to report on this procedure applied to eleven women with an average age of 44 years who had been refractory to hormone therapy or myomectomy. These authors used PVA (polyvinyl alcohol) particles of 500-700 $\mu$.

Worthington-Kirsh et al. (1998) analyzed 53 women with menorrhagic and/or compressive symptoms, almost all of whom were successfully treated with arterial embolization. ${ }^{8}$ Recently, McLucas (2001) found similar results in 167 patients submitted to uterine artery embolization. In a literature review, Hurst et al. (2000) concluded that the use of uterine artery embolization is increasing as an alternative for the treatment of women with uterine fibroids who refuse surgery, despite its lack of long-term efficacy and maintenance of future fertility. They suggest further wellcontrolled trials to establish the safety and efficacy of this new treatment. ${ }^{9,10}$

Thus, there is evidence that uterine artery embolization may become a method of practical applicability and good acceptability among women who wish to preserve their uterus. Nonetheless, further studies are needed

\section{......... ABSTRACT CONTEXT: Uterine myomas are benign tumors that mostly occur in women of reproductive age at a frequency ranging from 20 to $25 \%$. The symptoms are increased menstrual flow, pain and compressive signs. New treatments have been proposed and uterine artery embolization is one of them.}

OBJECTIVE: To evaluate the effects of treatment by em bolization of the uterine artery, in women with symptomatic myomas. Uterine and dominan myoma volumes and the major symptoms were evaluated before treatment and 12 weeks later.

TYPE OF STUDY: Open clinical trial.

SETTING: A tertiary-care women's hospital.

PARTICIPANTS: The study was conducted on 32 women with symptomatic single or multiple myomas of the uterine body, seen at the outpatient unit from May 2000 to September 2001.

MAIN MEASUREMENTS: The patients were submitted to gynecological examination and abdominal and endovaginal pelvic ultrasonography, and the examinations were repeated 12 weeks after the first procedure. Uterine artery embolization using PVA (polyvinyl alcoholl) particles of 355-700 $\mu$ was performed by catherization of the right femoral artery in 30 women and by bilateral catheterization in two.

RESULTS: Before embolization, the mean uterine voume of the 32 women was $455 \mathrm{~cm}^{3}$ and the mean volume of the dominant myoma was $150 \mathrm{~cm}^{3}$. Twelve weeks after embolization, the mean uterine volume was $256 \mathrm{~cm}^{3}$ and the mean volume of the dominant myoma was $91 \mathrm{~cm}^{3}$, with $p<0.0$ in both cases. Twelve weeks after the treatment all the women answered a questionnaire, which all the women answered a questionnaire, which
showed that $71 \%$ had improvement in menstrual regularity, $90 \%$ decreased menstrual volume and $81 \%$ shortened menstrual duration. The most fre quent immediate post-procedure symptoms, established as complications, were pain $(100 \%)$ and fatigue $(34 \%)$. One woman had myoma degeneration and was submitted to myomectomy.

CONCLUSION: The significant reduction in uterine and dominant myoma volume confirms the validity of the treatment of symptomatic myomas by the technique of uterine artery embolization in Brazilian women. There was significant reduction in men strual flow and duration, as well as better cycle regularity in the women studied. The few adverse regularity in the women studied. The few adverse
effects observed in the sample studied mainly in volved pain immediately after embolization.

KEY WORDS: Therapeutic embolization. Myoma. Uterine neoplasms. Uterine diseases. Treatment outcome. 
especially for evaluating the reproducibility of the technique and results obtained within the reality of women's healthcare in Brazil.

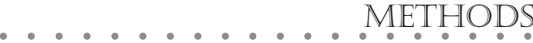

We selected women with a diagnosis of uterine myomatosis who wished to preserve their uteruses and who had been referred to the General Gynecology Outpatient Clinic of the Leonor Mendes de Barros Maternity Hospital. A total of 32 women with symptomatic myoma (mean age 40 years; range $27-51$ years) were recruited for the study between August 2000 and May 2001. Since this is a tertiary care service, the women were referred by a doctor of the public health network (SUS), with or without a previous ultrasound examination. The patients were then submitted to a new gynecological and ultrasound examination for better determination of uterine volume and the volumes of the myomas. The average volumes of uterus and dominant fibroid were $455 \mathrm{~cm}^{3}$ and $150 \mathrm{~cm}^{3}$ prior to uterine artery embolization. Ten percent of the women were nulliparous, $25 \%$ primiparous and $65 \%$ had had two or more pregnancies. All women declared that they had menstrual disorders (volume or duration increase) and 12 weeks later all the women were asked about the volume, regularity and duration of bleeding in order to establish the magnitude of the menstrual disorder. Women with previous surgical treatment or recent clinical treatment and women with pedunculated myoma were excluded.

All the women were informed of the aim of the study and gave their consent. This study was approved by the local ethical committee

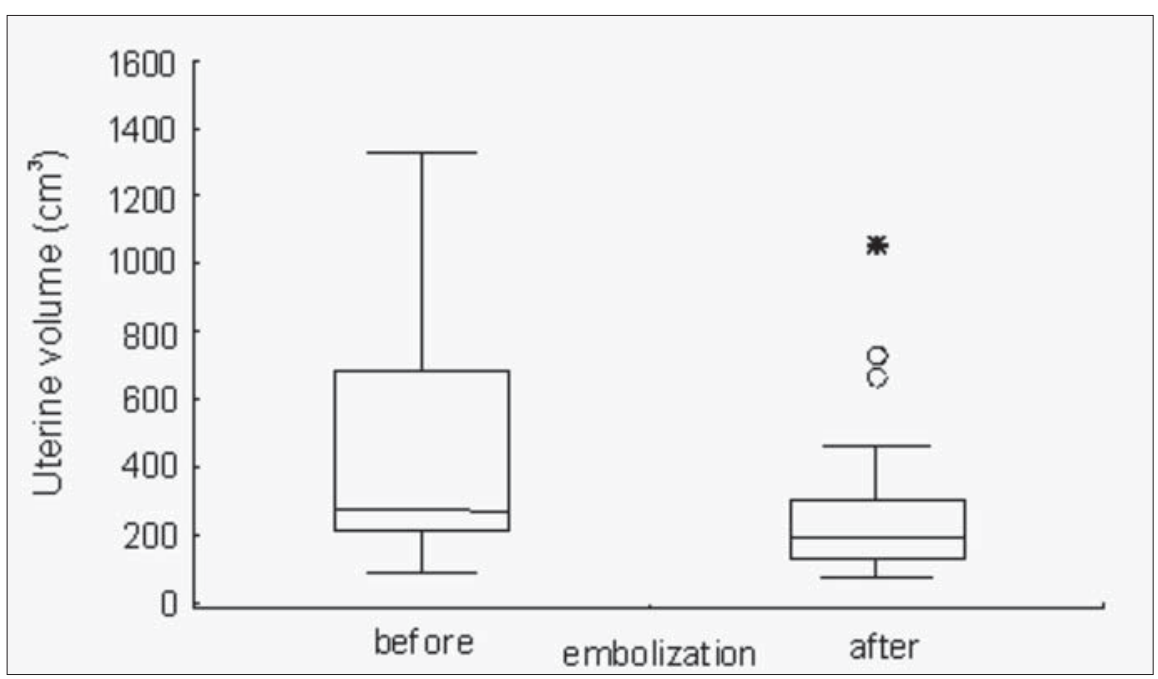

Figure 1. Comparison of the uterine volume before and after embolization. Wilcoxon test for paired samples, $p<0.01$.

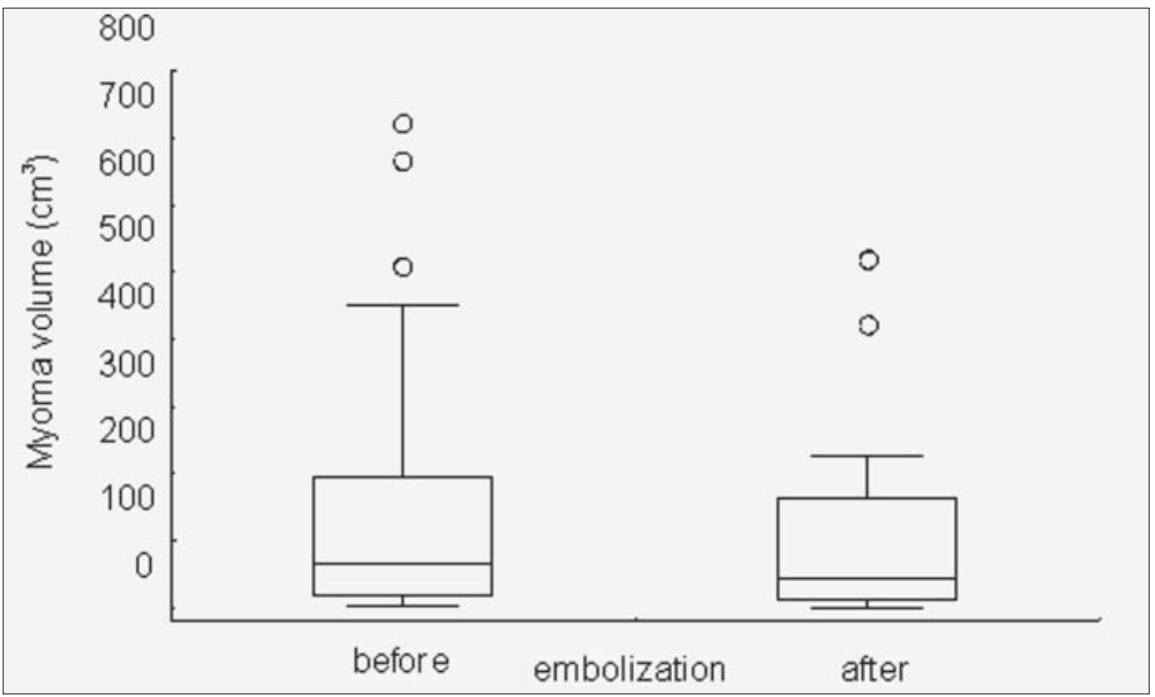

Figure 2. Comparison of the volumes of the dominant myoma before and after embolization. Wilcoxon test for paired samples, $p<0.01$.

from Hospital Leonor Mendes de Barros and also by the Brazilian National Research and Teaching Committee (CONEP), in compliance with the principles of the Helsinki Declaration, as reviewed in Hong Kong, and with adherence to good clinical practice. For statistical analysis, we used the Wilcoxon test.

\section{Techniques and examinations}

\section{Angiography and the method for uterine artery embolization}

The procedures utilized Shimadzu digital angiography apparatus, model Digitex 2400. Prophylactic antibiotic treatment and analgesia were administered.

The femoral arteries were palpated in the inguinal region and a local anesthetic was applied by infiltrating $2 \%$ lidocaine in order to permit vessel puncture using the Seldinger technique. ${ }^{11}$ The right femoral artery was punctured for the introduction of a guide cannula. An introducer with a $5 \mathrm{~F}$ anti-reflux valve $(1.66 \mathrm{~m})$ was then inserted and the guide cannula was removed. A pigtail-type catheter was then inserted through the introducing guide to the level of the aortic bifurcation and 30 $\mathrm{ml}$ of radiological contrast (meglumine diatrizoate and sodium diatrizoate, Hypaque ${ }^{\circledR}$ ) was injected for the angiographic study of the pelvis, in order to record the pelvic arterial map and identify the origin of the uterine arteries. The pigtail catheter was then replaced with a 5-F angiographic catheter of the femoral-visceral type (Dav, Cobra or Berestein).

The catheter was first advanced to the bifurcation of the aorta under fluoroscopic vision and positioned in the hypogastric artery. Selective catheterization was subsequently performed in the contralateral uterine artery. Contralateral uterine angiography was performed using approximately $10 \mathrm{ml}$ of contrast in order to visualize the vessel architecture of the uterine artery and the distribution of its branches. The embolization material was prepared as follows: 1 PVA flask containing 355$500 \mu$ or $500-700 \mu$ particles was added to 10 $\mathrm{ml}$ contrast, $1 \mathrm{ml} 0.9 \%$ physiological saline and one 40-mg ampoule of gentamicin. The material thus prepared was then injected through the angiographic catheter using small-volume syringes under fluoroscopic control, until vascular stasis and disappearance of the arched branches and the branches originating from the main trunk of the uterine artery were observed. A post-embolization angiographic check was performed at that time and documented on radiographic film. Using a procedure similar to that described above, ipsilateral catheteriza- 
tion of the hypogastric artery and uterine artery was performed via the Waltman maneuver, followed by ipsilateral uterine angiography, right artery embolization using PVA, and an angiographic check after embolization. The introducer and the catheter were removed and manual compression was performed over a mean time of 5 minutes until local homeostasis was obtained. Puncture of the left femoral artery was performed when the bilateral technique was absolutely necessary.

The women were instructed to return for follow-up and checks 1, 6 and 12 weeks after the procedure. Some women returned more frequently for signs or symptoms to be checked or for medication.

The patients admitted to the Leonor Mendes de Barros Maternity Hospital spent one to four days in the hospital (mean of two days) under the care of the investigating physician and doctors on shift duty, in order to obtain better control of pain or post-embolization syndrome. When the women returned for followup and checks 1, 6 and 12 weeks after the procedure, they gave responses to the continuation of the questionnaire, and were again submitted to clinical and ultrasound examination.

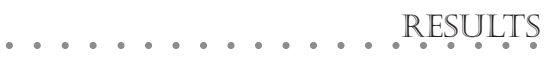

Uterine volume was significantly decreased after uterine artery embolization, in comparison with the volumes before uterine artery embolization (Figure 1). The smallest uterine volume was $84 \mathrm{~cm}^{3}$ before uterine artery embolization and $75 \mathrm{~cm}^{3}$ after uterine artery embolization. The largest uterine volume was $1,325 \mathrm{~cm}^{3}$ before uterine artery embolization and $1,055 \mathrm{~cm}^{3}$ after uterine artery embolization.

The difference in both the $25^{\text {th }}$ and $75^{\text {th }}$ quartiles of the dominant myoma volumes before and after uterine artery embolization was significant, as shown by the Wilcoxon test for paired samples $(\mathrm{p}<0.01)$ (Figure 2$)$. The volume of the dominant myomas was significantly decreased 12 weeks after uterine artery embolization. The smallest myoma size was $4 \mathrm{~cm}^{3}$ before uterine artery embolization, with total regression after the procedure. The largest myoma size was $722 \mathrm{~cm}^{3}$ before uterine artery embolization and $519 \mathrm{~cm}^{3}$ after uterine artery embolization. The values represented by circles in the graph were beyond the maximum value but still within the scale (Figure 2).

Of the 32 women submitted to uterine artery embolization and evaluated 12 weeks later, one was excluded because of myoma degeneration, and myomectomy was per- formed; 27 presented a mean of $42 \%$ reduction in uterine volume; while only 4 women presented an increase in mean uterine volume $(6 \%)$ after uterine artery embolization. With respect to the dominant myoma, there was a reduction in volume in 27 women and an increase in 3. In one woman there was no change in the volume of the dominant myoma (Table 1).

In 22 women there was better menstrual regularity 12 weeks after the procedure, 28 presented a reduction in menstrual volume and 25 declared a shorter duration (Table 2). The most frequent immediate complications were pain and fatigue. Myoma degeneration occurred in one woman who had a pedunculated myoma immured in the small pelvis. The patient was hospitalized and properly treated via myomectomy, with a satisfactory course that had no complications or sequelae. Myoma elimination by the vaginal route occurred in two women. There were no infectious complications or allergies relating to contrast, antibiotics or anesthetic agents (Table 3).

\begin{tabular}{lcccccccc} 
& \multicolumn{3}{c}{ Table 1. Percent variation in uterine and dominant myoma } \\
volumes 12 weeks after embolization* \\
Reduction in volume
\end{tabular}

*One woman was not included in this analysis and another one had no variation in myoma volume.

Table 2. Frequency distribution of women submitted to artery embolization according to changes in menstrual rhythm, after a 12-week period

\begin{tabular}{lccc} 
& \multicolumn{3}{c}{ Change in menstrual regularity } \\
& $\mathbf{n}$ & & $\%$ \\
Equal & 7 & & 22.6 \\
Regular & 22 & & 71.0 \\
Irregular & 2 & & 6.4 \\
& & Change in menstrual volume & \\
\hline & $\mathbf{n}$ & & $\%$ \\
\hline Equal & 3 & & 9.7 \\
Lower & 28 & & 90.3 \\
\hline & & Change in menstrual duration & \\
\hline & $\mathbf{n}$ & & $\%$ \\
\hline Equal & 6 & & 19.4 \\
\hline Shorter & 25 & & $\mathbf{1 0 0}$ \\
\hline Total & $\mathbf{3 1}$ & & \\
\hline
\end{tabular}

One woman (case 3) was not included in this analysis.

Table 3. Complications occurring immediately and up to 12 weeks after uterine artery embolization in 32 women

n

$\%$

Post-embolization syndrome

Pain

Fever (>37. ${ }^{\circ} \mathrm{C}$ )

$32 / 32$

$0 / 32$

$11 / 32$

Fatigue

$1 / 32$

Degeneration

Infection

Myoma elimination

$0 / 32$

$2 / 32$

Puncturing accident (hematoma) $\quad 3 / 32$

Allergy

$0 / 32$
(100) 


\section{DISCUSSION}

The main objective of the present investigation was to evaluate the characteristics of the uterus after uterine artery embolization in 32 Brazilian women with symptomatic myomas treated from August 2000 to September 2001.

The type of myomatosis may influence the decision to use the uterine artery embolization procedure in some selected cases. Multiple myomas for which the surgical approach is difficult, giant myomas with marked compressive symptoms, or clinically intractable myomas for which the only option would be hysterectomy even among young women, could be submitted to uterine artery embolization if the patient wished to keep her uterus. ${ }^{12}$ It should also be pointed out that abdominal or laparoscopic myomectomy, which could be another option for women with multiple myomas, presents complications such as adhesions, development of new myomas, and the possibility of conversion to hysterectomy. ${ }^{13}$ One of the patients in our series, a 27 -year-old woman, presented a satisfactory result both in anatomical and symptomatic terms, a fact that has stimulated us to consider this alternative more frequently.

Most of the women submitted to uterine artery embolization presented a mean reduction in uterine volume and dominant myoma volume of about half the initial volume after 12 weeks. With respect to the major symptoms, the best result was the reduction in menstrual flow observed in almost all women in this series. Greater regularity of the menstrual cycle and an effective reduction in the number of days of menstruation were also observed.

In our study, the main symptom reported by the patients was an increase in menstrual flow, present in all cases, associated with pelvic pain in some cases $(13 \%)$ or with increased abdominal volume (3\%). These findings agree with those reported by most investigators, who stated that 85 to $100 \%$ of embolized women had menorrhagia as the major symptom. ${ }^{6,8}$

Our results are closely similar to those obtained at other centers, since we obtained a reduction in menstrual flow in $90 \%$ of our patients (28 with an effective decrease in flow and three with no changes), indicating good reproducibility of the current uterine artery embolization technique. In addition to menstrual flow, we believe that it is important to consider two more features concerning menstruation, i.e. regularity of the cycle and menstrual duration. Better regularity in these pa- rameters was observed in $71 \%$ of cases, with seven women maintaining regular cycles and two continuing to have irregular cycles. There was also a decrease in the number of days of menstruation in $80 \%$ of the women, while no change in duration was observed in the remaining women. ${ }^{14}$

Twelve weeks after uterine artery embolization, two of the 32 women studied (one of them was excluded) presented amenorrhea. One was a 47-year-old severely hypertensive woman with no vasomotor symptoms and a follicle-stimulating hormone (FSH) level of $25.9 \mathrm{mIU} / \mathrm{ml}$, and the other was a 50 -yearold woman with FSH of $16.9 \mathrm{mIU} / \mathrm{ml}$, who started to have regular cycles again. Ovarian failure after uterine artery embolization was first reported by Stringer et al. (2000). Spies et al. (2001) studied 63 patients after uterine artery embolization and concluded that, while most patients had no change in ovarian function as measured by basal FSH, for patients aged 45 or older there is an approximately $15 \%$ chance of an increase in basal FSH into the perimenopausal range. Hysterectomy was not necessary in any of our cases, confirming the studies cited earlier, but one woman was submitted to myomectomy because of undiagnosed pedunculated myoma. ${ }^{15,16}$

Another important aspect of our series was the low rate of complications during the examinations, such as vasospasms, and immediately after them, such as puncture hematomas. This reflected the excellence of the techniques used by the operating radiologist and the nursing team providing the postoperative care.

In the present study, uterine volume showed a mean decrease of $40 \% 12$ weeks after uterine artery embolization, in agreement with most other studies. From the initial report by Ravina et al. (1995) up to current studies, the decreases in uterine volume found have ranged from 27 to $51 \%$, most frequently corresponding to 40 to $44 \% .^{6-8,17-23}$

Bradley et al. (1998) reported the highest rate of reduction $(51 \%)$, in eight women with symptomatic myomas that had a mean volume of $1,300 \mathrm{~cm}^{3}$ before embolization. This result can be better understood by considering two factors: volume-dependence, i.e. the larger the initial volume, the greater the percentage reduction after uterine artery embolization; and the use of a more sensitive method for the evaluation, i.e. nuclear magnetic resonance. ${ }^{12}$

Most of the women studied here had uterine volumes of less than $300 \mathrm{~cm}^{3}$ and we opted for the use of combined ultrasound when necessary, with evaluation performed by the same examiner and the same equipment before and after embolization, in order to reduce the inter-observer and equipment-dependent error.

In our sample, four women showed a mean increase of $5 \%$. This slight, non-significant increase may be explained by the range of variation in reliability of the method and it was observed in uteri with volumes of less than $200 \mathrm{~cm}^{3}$. These results lead us to infer that the small differences in measurements observed 12 weeks after uterine artery embolization may have masked the evaluation of uteri of smaller volume in terms of percent variation in comparison with uteri of larger volume.

In our series, the four women who did not show a reduction in uterine volume, as mentioned earlier, also showed a significant improvement in the main symptom. These results were a little less expressive than those reported in most of the published studies, which showed a mean reduction of 43 to $60 \%{ }^{7,17-19,21,23-27}$ This may be explained by two factors, i.e. the characteristics of the uterus embolized in this study, which in most cases had a volume of less than $300 \mathrm{~cm}^{3}$; and the time when the evaluation was performed, which in our study was 12 weeks.

Of the 31 women studied here whose follow-up was concluded after 12 weeks (one was submitted to myomectomy before this time), four did not present a reduction in the dominant myoma. One of them continued to have a stationary volume, two showed a non-significant decrease, and the last showed a considerable increase from 236 to $519 \mathrm{~cm}^{3}$. This increase was possibly due to asymptomatic degeneration of the myoma, with no need for any intervention. There was an $18 \%$ reduction in uterine volume and, as a precautionary measure, the return visits of these patients were scheduled at higher frequency.

It is interesting to note that most of these women were already starting to present marked reduction in flow during the first menstrual episode. These data agree with those reported by Pelage et al. (2000) who observed improved menstrual flow in the first cycle in $92 \%$ of cases. ${ }^{20}$

In our sample, one woman was submitted to myomectomy eight weeks after uterine artery embolization because she presented hyaline degeneration in a voluminous and pedunculated myoma whose pedicle was not identified by clinical examination or ultrasound because it was fixed to the smaller pelvis. Another woman eliminated myoma fragments by the vaginal route and was submitted to curettage of the uterus. In the same 
way as reported by Berkowitz et al. (1999) and Abbara et al. (1999), this patient also experienced strong cramps associated with slight bleeding, especially at the time of elimination. In our sample, all patients experienced pelvic pain of differing degrees after embolization, using the established pain protocol (treated with ketoprofen $100 \mathrm{mg}$ IV, meperidine $100 \mathrm{mg}$ ). None of them used epidural anesthesia. ${ }^{28,29}$

Andersen et al. (2001) used, on average, three PVA flasks of particles measuring 355$500 \mu$ in 62 women..$^{30}$ We used, on average, two particle flasks, perhaps because of the elasticity of the use of different particle sizes, or because we established technical success when we observed the absence of flow and retention of contrast in the uterus, known as the parenchymatous phase of embolization, an event that sometimes varies from one report to another. ${ }^{30}$

From a technical viewpoint, we observed the importance of the gynecologist's participation in the judicious selection of cases, explaining the technique to be adopted for the patient, answering patients' queries and, especially, transmitting security through his presence on the day of the procedure. In addition, the increasing experience and consequent greater skill of the operating radiologist may lead to more rapid embolization procedures, with gradually reduced exposure to radiation. $\ldots . . . .$. CONCLUSION

In conclusion, the significant reduction in the uterine and dominant myoma volumes has confirmed the validity of the treatment of symptomatic myomas by uterine artery embolization. Among the symptoms that had been present before the procedure, there was significant reduction in menstrual flow and duration, as well as better regularity of the cycle in the women studied. Few adverse effects were observed, mainly represented by pain immediately after embolization, further indicating the feasibility of using this procedure for the treatment of selected cases of women with symptomatic myomas.

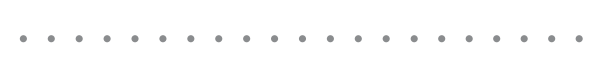

1. Brosens IA, Lunenfeld B, Donnez J. Pathogenesis and medical management of uterine fibroids. London: Parthenon Publishing Group; 1999.

2. Cramer SF, Patel A. The frequency of uterine leiomyomas. Am J Clin Pathol 1990;94(4):435-8.

3. ACOG practice bulletin. Surgical alternatives to hysterectomy in the management of leiomyomas. Number 16, May 2000 (replaces educational bulletin number 192, May 1994). Int J Gynaecol Obstet 2001;73(3):285-93.

4. Gross CP, Anderson GF, Powe NR. The relation between funding by the National Institutes of Health and the burden of disease. N Engl J Med 1999;340(24):1881-7.

5. Chavez NF, Stewart EA. Medical treatment of uterine fibroids. Clin Obstet Gynecol 2001;44(2):372-84

6. Ravina JH, Herbreteau D, Ciraru-Vigneron N, et al. Arterial embolisation to treat uterine myomata. Lancet 1995;346(8976):671-2.

7. Goodwin SC, Vedantham S, McLucas B, Forno AE, Perrella R. Preliminary experience with uterine artery embolization for uterine fibroids. J Vasc Interv Radiol 1997;8(4):517-26.

8. Worthington-Kirsch L, Walker WJ, Adler L, Hutchins Jr FL. Anatomic variation in the uterine arteries: a cause of failure of uterine artery embolisation for the management of symptomatic myomata. Min Invas Ther \& Allied Technol 1998;8(6):397-402.

9. McLucas B, Adler L, Perrella R. Uterine fibroid embolization: nonsurgical treatment for symptomatic fibroids. J Am Coll Surg 2001;192(1):95-105.

10. Hurst BS, Stackhouse DJ, Matthews ML, Marshburn PB. Uterine artery embolization for symptomatic uterine myomas. Fertil Steril 2000;74(5):855-69

11. Seldinger SI. Catheter replacement of needle in percutaneous arteriography. A new technique. Acta Radiol 1953;39:368-76.

12. Bradley EA, Reidy JF, Forman RG, Jarosz J, Braude PR. Transcatheter uterine artery embolisation to treat large uterine fibroids. Br J Obstet Gynaecol 1998;105(2):235-40.

13. Subramanian S, Clark MA, Isaacson K. Outcome and resource use associated with myomectomy. Obstet Gynecol 2001;98(4):583-7.

14. Worthington-Kirsch RL. Flow redistribution during uterine artery embolization for the management of symptomatic fibroids. J Vasc Interv Radiol 1999;10(2 Pt 1):237-8.

15. Stringer NH, Grant T, Park J, Oldham L. Ovarian failure after uterine artery embolization for treatment of myomas. J Am Assoc Gynecol Laparosc 2000;7(3):395-400.

16. Spies JB, Roth AR, Gonsalves SM, Murphy-Skrzyniarz KM. Ovarian function after uterine artery embolization for leiomyomata: assessment with use of serum follicle stimulating hormone assay. J Vasc Interv Radiol 2001;12(4):437-42.

17. Pelage JP, Walker WJ, Le Dref O, et al. Treatment of uterine fibroids. Lancet 2001;357:(9267):1530.

18. Goodwin SC, McLucas B, Lee M, et al. Uterine artery embolization for the treatment of uterine leiomyomata midterm results. J Vasc Interv Radiol 1999;10(9):1159-65.

19. Spies JB, Warren EH, Mathias SD, Walsh SM, Roth AR, Pentecost MJ. Uterine fibroid embolization: measurement of healthrelated quality of life before and after therapy. J Vasc Interv Radiol 1999;10(10):1293-303.

20. Pelage JP, Le Dref O, Soyer P, et al. Fibroid-related menorrhagia: treatment with superselective embolization of the uterine arteries and midterm follow-up. Radiology 2000;215(2):428-31.

21. Ravina JH, Aymard A, Ciraru-Vigneron N, Ledreff O, Merland JJ. Embolisation artérielle des myomes utérins. J Gynecol Obstet
Biol Reprod 2000;29(3):272-5.

22. Siskin GP, Englander M, Stainken BF, Ahn J, Dowling K, Dolen EG. Embolic agents used for uterine fibroid embolization. AJR Am J Roentgenol 2000;175(3):767-73.

23. Klein A, Schwartz ML. Uterine artery embolization for the treatment of uterine fibroids: an outpatient procedure. Am J Obstet Gynecol 2001;184(7):1556-60; discussion 1560-3.

24. Burn P, McCall J, Chinn R, Healy J. Embolization of uterine fibroids. Br J Radiol 1999;72(854):159-61.

25. Burn PR, McCall JM, Chinn RJ, Vashisht A, Smith JR, Healy JC. Uterine fibroleiomyoma: MR imaging appearances before and after embolization of uterine arteries. Radiology 2000;214(3):729-34.

26. Ravina JH, Bouret JM, Ciraru-Vigneron N, et al. Recourse to particular arterial embolization in the treatment of some uterine leiomyoma. Bull Acad Natl Med 1997;181(2):233-43; discussion 244-6.

27. Ravina JH, Herbreteau D, Ciraru-Vigneron N, et al. Arterial embolisation to treat uterine myomata. Lancet 1995;346(8976):671-2.

28. Berkowitz RP, Hutchins FL, Worthington-Kirsch RL Vaginal expulsion of submucosal fibroids after uterine artery embolization. A report of three cases. J Reprod Med 1999;44(4):373-6.

29. Abbara S, Spies JB, Scialli AR, Jha RC, Lage JM, Nikolic B. Transcervical expulsion of a fibroid as a result of uterine artery embolization for leiomyomata. J Vasc Interv Radiol 1999;10(4):409-11.

30. Andersen PE, Lund N, Justesen P, Munk T, Elle B, Floridon C. Uterine artery embolization of symptomatic uterine fibroid. Initial success and short-term results. Acta Radiol 2001;42(2):234-8. 


\section{. PUBLISHING INFORMATION}

Maurício Sena-Martins, MD, PhD. Hospital Leonor Mendes de Barros, São Paulo, Brazil.

Cecilia Maria Roteli-Martins, MD, PhD. Hospital Leonor Mendes de Barros, São Paulo, Brazil.

Valdir Tadini, MD, PhD. Hospital Leonor Mendes de Barros, São Paulo, Brazil.

Gustavo Antonio de Souza, MD, PhD. Department of Gynecology, Universidade de Campinas, Campinas, São Paulo, Brazil.

Nestor Kisilevzky, MD. Hospital Leonor Mendes de Barros, São Paulo, Brazil.

Felipe Lazar Junior, MD. Hospital Leonor Mendes de Barros, São Paulo, Brazil.

Sources of funding: Not declared

Conflict of interest: Not declared

Date of first submission: August 20, 2002

Last received: January 30, 2003

Accepted: February 14, 2003

\section{Address for correspondence:}

Maurício Sena-Martins

Av. Angélica, 1968 - cj. 33

São Paulo/SP - Brasil - CEP 01228-200

Tel. (+551 1) 3825-9643

E-mail: mauriciosena@uol.com.br

$\ldots \ldots \ldots \ldots \ldots \ldots \ldots$ REMU

Embolização da artéria uterina para o tratamento de miomas sintomáticos em mulheres brasileiras

CONTEXTO: Miomas uterinos são tumores benignos que ocorrem na idade reprodutiva das mulheres com uma frequiência que varia entre $20 \%$ a $25 \%$. Quando presentes os sintomas, estes se caracterizam por aumento do fluxo menstrual, dor e sinais de compressão. Têm sido propostas novas formas de tratamento, destacando-se a embolização das artérias uterinas.

OBJETIVO: Avaliar os efeitos do tratamento com embolização das artérias uterinas em mulheres portadoras de miomas sintomáticos e os volumes uterino e do mioma dominante, antes e após 12 semanas após o procedimento.

TIPO DE ESTUDO: Ensaio clínico aberto.

LOCAL: Hospital Leonor Mendes de Barros, São Paulo, Brasil.

PARTICIPANTES: 32 mulheres com diagnóstico de mioma sintomático, único ou múltiplo, do corpo uterino, atendidas no Ambulatório de Ginecologia do Hospital Leonor Mendes de Barros, entre maio de 2000 e setembro de 2001.

VARIÁVEIS ESTUDADAS: As mulheres foram submetidas a exame ginecológico seguido de ultra-sonografia abdominal, pélvica e endovaginal, repetidos 12 semanas após o procedimento. A embolização da artéria uterina com PVA (partículas de álcool polivinil de 355 a $700 \mu$ ) foi realizada através da cateterização da artéria femoral direita em 30 mulheres e, em duas mulheres, a cateterização foi bilateral.

RESULTADOS: A média do volume uterino de 32 mulheres antes da embolização foi 455 $\mathrm{cm}^{3}$ e a média do volume do mioma dominante foi de $150 \mathrm{~cm}^{3}$ antes da embolização. Após 12 semanas de embolização, média do volume uterino e do mioma dominante foram $256 \mathrm{~cm}^{3}$ e $91 \mathrm{~cm}^{3}$ respectivamente. A redução dos volumes uterino e do mioma dominante foi estatisticamente significativa $(\mathrm{p}<0,01)$ quando usado o teste de Wilcoxon. Doze semanas após o tratamento, questionário respondido por todas as mulheres mostrou melhor regularidade menstrual em $71 \%$, redução do volume menstrual em $90 \%$ e menor duração em $81 \%$. As complicaçóes imediatas mais freqüentes foram dor e fadiga. Apenas em uma mulher ocorreu degeneração do mioma.

CONCLUSÃO: A significativa diminuição dos volumes uterinos e dos miomas dominantes comprova a validade do tratamento dos miomas sintomáticos pela técnica de embolização das artérias uterinas. Houve uma redução significativa do fluxo e da duração menstrual, assim como uma melhor regularidade do ciclo nas mulheres estudadas. Nesta amostra, a dor imediata após a embolização foi o principal evento adverso observado.

PALAVRAS-CHAVE: Embolização terapêutica. Mioma. Neoplasias dos genitais femininos. Útero. Resultado de tratamento. 